\title{
The Monoglyceride Pathway of Fat Absorption in Man*
}

\author{
Herbert J. Kayden, $\ddagger$ Joh n R. Senior, and Fred H. Mattson \\ (From the Department of Medicine, New York University School of Medicine, New York, the \\ Philadelphia General Hospital and University of Pennsylvania, Philadelphia, Pennsyl- \\ vania, and Miami Valley Laboratories, Procter and Gamble Co., Cincinnati, Ohio)
}

\begin{abstract}
The absorption of fat was studied in five male subjects with cannulation of the thoracic duct in the neck by the administration of doubly labeled monoglycerides, or triglyceride as well as labeled free glycerol or labeled free oleic acid, by gastric or duodenal intubation.

Total recoveries of the administered glyceride radioactivity from the lymph lipids ranged from 35 to $53 \%$ for the glycerol label (tritium) and from 35 to $57 \%$ for the fatty acid label $\left({ }^{14} \mathrm{C}\right)$. The recovery of administered radioactive free glycerol in lymph lipids was only $4.1 \%$, even when given in mixture with bile salts, fatty acid, and monoglyceride.

A comparison of the isotope ratios of the two components (glycerol and fatty acid) of the lymph glycerides with the ratios of these components of the original meal glyceride showed little change during the initial period of fat absorption, indicating that the doubly labeled monoglycerides passed into the lymph intact. During the later part of the period of major fat absorption, the ratios in lymph lipids changed due to loss of glycerol representation, indicating monoglyceride hydrolysis and portal venous diversion of free glycerol.

Confirmation of the intact nature of 2-monoglyceride during absorption was made by analyzing the amount and position of the labeled fatty acid in the lymph triglycerides. The percentage of labeled fatty acid in the various positions of the lymph triglycerides was virtually identical with that of the meal during the initial period of fat absorption and then changed reflecting isomerization of fatty acids and subsequent complete hydrolysis of the glycerides.
\end{abstract}

The 2-monoglyceride pathway appears to be the major route of fat absorption for man during normal digestion and absorption of dietary triglyceride.

\section{Introduction}

The major portion of dietary fat is insoluble in water and important changes take place in the physicochemical state of dietary triglycerides in

* Received for publication 16 August 1966 and in revised form 18 July 1967.

Presented at the Annual Meeting of American Society for Clinical Investigation 2 May 1966, Atlantic City, N. J. and published in abstract form (1).

$¥$ Recipient of Research Career Development Award K3 HE 14-828.

Supported by Grants HE 06481, and AM 06377, National Institutes of Health, U. S. Public Health Service.

Address requests for reprints to Dr. Herbert J. Kayden, New York University School of Medicine, 550 First Avenue, New York, N. Y. 10016. the gut lumen before absorption into the intestinal epithelium. Complete hydrolysis of triglyceride yields free fatty acids and glycerol ; partial hydrolysis results in free fatty acids, monoglycerides, and diglycerides. Recently, it was shown in man that monoglycerides, free fatty acids, and conjugated bile salts readily form ultrafine aggregates or micellar solutions, from which fatty acids and monoglycerides may be absorbed into the intestinal mucosal cells (2). In whole animal studies, in which the glycerol and fatty acid moieties of glycerides were labeled with different isotopes, it was demonstrated (3-5) that 2-monoglycerides remain largely intact during intestinal absorption and reesterification into chylomicron triglycerides. This 
direct acylation pathway of monoglycerides to higher glycerides appears to be uniquely active in intestinal tissue, and is not appreciably demonstrable in other sites of triglycerides synthesis, such as the liver (6).

The present studies were undertaken to investigate glyceride absorption in man by administering singly and doubly labeled lipid compounds and analyzing in the subsequent hours lymph obtained by thoracic duct cannulation. The particular goal was to determine whether the monoglyceride pathway that has been shown in animals is also present in man and to attempt to assess its quantitative importance during normal fat absorption. The results of these studies suggest that the monoglyceride pathway is the predominant one during normal fat absorption.

\section{Methods}

Materials. The test glycerides were $2-{ }^{3} \mathrm{H}$-glycerolmonostearate- $1^{1}{ }^{14} \mathrm{C}$ in which the stearic acid was in the 1- or 2-position and $2{ }^{3} \mathrm{H}$-glycerol-1,3-dioleate-2-oleate-1'${ }^{14} \mathrm{C}$. The monostearin was synthesized from stearic acid$1-{ }^{14} \mathrm{C}$ and glycerol-2- ${ }^{3} \mathrm{H}$ obtained from New England $\mathrm{Nu}-$ clear Corp., Boston, Mass. Carrier stearic acid (Applied Science Laboratories Inc., State College, $\mathrm{Pa}$.) was 99.8\% pure (gas-liquid chromatography) and glycerol (Merck) was freshly redistilled at $2 \mathrm{~mm} \mathrm{Hg}$ pressure. The method of preparation of 2-monostearin has been previously described (7). The final product had a specific activity of $30 \mu \mathrm{c} / \mathrm{mg}$ for ${ }^{3} \mathrm{H}$ and $15 \mu \mathrm{c} / \mathrm{mg}$ for ${ }^{14} \mathrm{C}$. On hydroxylapatite thin-layer chromatography it moved as a single spot from which $98 \%$ of the radioactivity could be recovered. Saponification of the eluted material from the spot and partition between petroleum ether and acidified water phases showed that all the measurable ${ }^{14} \mathrm{C}$ activity was in the fatty acid and the ${ }^{3} \mathrm{H}$ in the glycerol moiety. The doubly labeled 2-monostearin was stored dry at $-20^{\circ} \mathrm{C}$ but nevertheless showed gradual isomerization spontaneously to the 1-isomer. At the time of use in Study I, the material assayed 70\% 2-monostearin, 30\% 1-monostearin. The preparation of the micellar solution in Study II involved warming and some alkalinization, which appeared to enhance the isomerization so that assay of the final product instilled showed $20 \%$ 2-monostearin and 80\% 1-monostearin.

The labeled triolein was prepared from oleic acid- $1-{ }^{14} \mathrm{C}$ and glycerol $-2 \cdot{ }^{8} \mathrm{H}$, as previously described (7). For these studies a mixture of $2-{ }^{3} \mathrm{H}$-glycerol trioleate and glycerol-1, 3-dioleate-2-oleate- $1^{1}-{ }^{14} \mathrm{C}$ in the ratio of approximately $10: 1$ provided a specific activity of $1.6 \mu \mathrm{c} /$ $\mathrm{mg}$ for ${ }^{3} \mathrm{H}$ and $0.16 \mu \mathrm{c} / \mathrm{mg}$ for ${ }^{14} \mathrm{C}$. Verification of the purity of these glycerides was carried out frequently over the course of many months by thin-layer and gasliquid chromatography and by enzymatic hydrolysis. The purity of the glycerides was within $4 \%$ of the indicated composition of each compound at the time of each study.

Experimental design. In each instance the test glyceride was administered after a 10-12 hr fast. Patients were studied in the Clinical Research Center of New York University School of Medicine at Bellevue Hospital. Five male patients were the subjects for this study. Thoracic duct cannulation was carried out in four of the patients for therapeutic or diagnostic reasons related to their primary disorder; one patient, W.H., was a volunteer.

B.B. was a $50 \mathrm{yr}$ old Negro male with a history of rheumatoid arthritis for 3 yr before study. Thoracic duct cannulation was performed for study of rheumatoid factor in lymph. The test meal for this patient was $120 \mathrm{mg}$ of a mixture of 1- and 2-isomers, in a ratio of $30: 70$, of doubly labeled monostearin made into micellar solution with $2 \mathrm{ml}$ of Emulphor EL 620,1 and $23 \mathrm{ml}$ of carbon dioxide-free water at $40^{\circ} \mathrm{C} .20 \mathrm{ml}$ of the solution was instilled via Miller-Abbott tube into the duodenum, and the tube flushed with warmed water and withdrawn. 2 $\mathrm{hr}$ later the patient was given $100 \mathrm{~g}$ of beef, and $200 \mathrm{ml}$ of fruit juice; $3 \mathrm{hr}$ later he began a regular diet and was encouraged to take fluids. Egg nogs were frequently given to maintain fluid and caloric balance; the marked variations in triglyceride content of the lymph samples reflect both fluid and fat content of the diet. Collections were continued for $48 \mathrm{hr}$.

J.K. was a $73 \mathrm{yr}$ old white man with known hypertension for $3 \mathrm{yr}$. Admission to the hospital was prompted by abdominal pain. Exploratory laparotomy revealed a large retroperitoneal lymphosarcoma. It was planned to treat this tumor by retrograde instillation of streptonigrin into the thoracic duct. The monoglyceride study was carried out 2 days after cannulation and before any anti-tumor therapy. The test meal for this patient was $180 \mathrm{mg}$ of a mixture of 1- and 2-isomers, in a ratio of $80: 20$, of doubly labeled monostearin in a micellar solution; the monostearin was dissolved in $4 \mathrm{ml}$ of ethyl ether to which $0.5 \mathrm{~g}$ of oleic acid dissolved in $3 \mathrm{ml}$ of ethyl alcohol was added. Pure sodium taurocholate, $0.5 \mathrm{~g}$, was dissolved in $20 \mathrm{ml}$ of warmed phosphate-buffered saline solution $\left(15 \mathrm{ml}\right.$ of $0.01 \mathrm{M} \mathrm{NaH}{ }_{2} \mathrm{PO}_{4}, 30 \mathrm{ml}$ of $0.01 \mathrm{M}$ $\mathrm{Na}_{2} \mathrm{HPO}_{4}$, and $40 \mathrm{ml}$ of $0.45 \% \mathrm{NaCl}$ ). The bile saltphosphate buffer mixture was added to the warmed etheralcohol-fatty acid-monostearin mixture with continued mixing and heating until ether odor was no longer detectable. The initial $\mathrm{pH}$ was 6 and $\mathrm{NaOH}(1 \mathrm{~N})$ was added until the $\mathrm{pH}$ was 7.2 ; the solution was initially cloudy but became water clear with formation of a stable micellar solution at $\mathrm{pH} 7.2$. $20 \mathrm{ml}$ of this solution was introduced into the duodenum and the tube was washed with $15 \mathrm{ml}$ of additional warm water and withdrawn. Regular feedings were started $6 \mathrm{hr}$ later. These also included egg nogs which markedly altered the flow and fat content of the lymph. The cannula became occluded $16 \mathrm{hr}$ after feeding of the test meal, and no additional lymph was collected. Radioactivity was noted in the 3 and $6 \mathrm{hr}$ samples.

1 Emulphor EL 620, polyoxyethylene triricinoleate, General Aniline \& Film Corporation, New York, N. Y. 
W.H. was a $55 \mathrm{yr}$ old white man admitted because of purpura and peripheral vascular disease. Extensive hematologic study failed to reveal any cause of the purpura. Thoracic duct cannulation was carried out for study of labeled triolein absorption. Duodenal intubation was unsuccessful in this patient. $1 \mathrm{hr}$ before the administration of the radioactive meal, $40 \mathrm{~g}$ of triolein and $100 \mathrm{ml}$ of fruit juice were given by mouth. The labeled triolein was mixed with aspirated gastric contents and reinjected into the gastric tube. Additional warmed water was given and the tube withdrawn. Fluids were given $2 \mathrm{hr}$ later and regular meals $6 \mathrm{hr}$ later. Egg nogs were used as supplementary feedings. Collections via cannula were continued for $36 \mathrm{hr}$. Virtually no radioactivity was recovered in the $0-2 \mathrm{hr}$ collection after feeding. Radioactivity was detected in plasma samples at $2 \mathrm{hr}$ after the test meal.

E.G., a 59 yr old white man, was admitted because of a recurrent pulmonary infection associated with his chronic pulmonary disease. Thoracic duct cannulation was performed at the time of a supraclavicular lymph node biopsy; the thoracic duct lymph and lymph node were studied for acid fast infection, neoplasm, granulomata, and fungi. The labeled triolein study was carried out on the first afternoon after cannulation; the study of the absorption of labeled free oleic acid and unlabeled triolein was performed on the $3 \mathrm{rd}$ day after cannulation and $42 \mathrm{hr}$ after the labeled triolein study. The patient was given $30 \mathrm{~g}$ of unlabeled triolein mixed with fruit juice. Onehalf hour later, intestinal contents were aspirated from a tube previously passed into the duodenum. About $7 \mathrm{ml}$ of the intestinal aspirate was mixed with the doubly labeled triolein and $0.5 \mathrm{ml}$ of unlabeled triolein, and a homogeneous emulsion was formed by sonication with a BioSonik Model II Sonicator (Bronwill Scientific, Division of Will Scientific, Inc., Rochester N. Y.) for $30 \mathrm{sec}$. This material was introduced into the tube and the tube flushed with tap water. The tube was withdrawn $30 \mathrm{~min}$ later. The patient received a normal diet $2.5 \mathrm{hr}$ after the triolein; lymph samples were continually collected from the time of surgery, for $42 \mathrm{hr}$. Radioactivity was noted in the $6 \mathrm{hr}$ sample. The labeled oleic acid-unlabeled triolein study (Study V) was begun, in this patient, when radioactivity in lymph samples had fallen to a low level. 20 $\mathrm{ml}$ of unlabeled triolein and $50 \mu \mathrm{c}$ of oleic acid-1- ${ }^{14} \mathrm{C}$ (specific activity $24.6 \mathrm{mc} / \mathrm{mm}$ ) were mixed with tomato juice and taken orally by the patient. During the $16 \mathrm{hr}$ before the test meal solid food had been withheld but fluids were freely given. The patient's usual diet was resumed $2 \mathrm{hr}$ after the labeled oleic acid-unlabeled triolein mixture had been ingested.

S.P., a 36 yr old white man, was admitted because of chronic alcoholism for $16 \mathrm{yr}$, and ascites for 2 months. Diuresis was obtained after salt restriction, and abdominal paracentesis of 1 liter. Thoracic duct cannulation was carried out to assay pancreatic enzyme activity in thoracic duct lymph. The radioactive glycerol study was carried out on the 4th day after cannulation. Glycerol- ${ }^{14} \mathrm{C}$ (40 $\mu \mathrm{c}$ ) obtained from Nuclear-Chicago was mixed with 10 $\mathrm{ml}$ of warm water. A micellar solution was made as follows. $\mathrm{Na}$ taurocholate $0.484 \mathrm{~g}$ and $\mathrm{Na}$ glycocholate $1.288 \mathrm{~g}$ (Nutritional Biochemicals Corp., Cleveland, Ohio) were dissolved in phosphate buffer $(0.077 \mathrm{M} \mathrm{NaCl}: 0.005$ м $\mathrm{Na}_{2} \mathrm{HPO}_{4}$. Monoolein $0.56 \mathrm{~g}$, heptadecanoic acid 1.025 $\mathrm{g}$, palmitic acid $0.96 \mathrm{~g}$, and unlabeled glycerol $0.138 \mathrm{~g}$ were dissolved in ethyl alcohol: ethyl ether mixture $3: 5$ $(\mathrm{v} / \mathrm{v})$. The buffered bile salts were added to the etheralcohol lipid solution with continuous stirring and heating to $45^{\circ} \mathrm{C}$. The solution (total volume $150 \mathrm{ml}$ ) was clarified by the addition of $\mathrm{NaOH}$ to $\mathrm{pH}$ 7.1. The solution was administered by intraduodenal tube during a $45 \mathrm{~min}$ period; the $10 \mathrm{ml}$ of radioactive glycerol solution was admixed with the micellar solution at 35 min after start of instillation, and the tube flushed with additional nonradioactive solution.

Analytic procedures. Lymph samples were collected into iced containers and stored at $4^{\circ} \mathrm{C}$ until analyzed. The samples were strained through gauze, the volumes recorded, and an appropriate fraction extracted with 20 volumes of chloroform: methanol $2: 1(\mathrm{v} / \mathrm{v})$. Separation into two layers was achieved by either large volumes of acid water $\left(0.05 \% \mathrm{H}_{2} \mathrm{SO}_{4}\right)$ or by smaller volumes of the dilute acid with centrifugation and washing of the chloroform fraction three times (8). Chloroform extracts were taken to dryness, and scintillant solution (2,5-diphenyloxazole, $4 \mathrm{~g}$ per liter of toluene, and 1,4-bis [2-(4-methyl5-phenyloxazoly1)] benzene $100 \mathrm{mg}$ per liter of toluene) was added. Samples were counted in a Tri-Carb (Packard) liquid scintillation spectrometer. Correction was made for isotope overlap in each channel; disintegrations per minute were calculated from efficiency data using known standards. Samples of the original meal were extracted in similar fashion and counted. Plasma samples were treated similarly. Quenching activity was approximately the same for all samples.

Triglyceride analysis was carried out on extracts of lymph by the method of Van Handel and Zilversmit (9) ; total lipids were estimated by the potassium dichromate method of Bragdon (10). Chylomicron fractions were prepared from lymph samples by centrifugation in a Spinco Model L ultracentrifuge at $26,000 \mathrm{~g}$ at $15^{\circ} \mathrm{C}$ either in a No. 40 rotor or in a No. 20 rotor. The creamy top layer was suspended in buffered phosphateEDTA solutions and respun as previously described by Kayden, Karmen, and Dumont (11). Lymph and chylomicron fractions were separated by thin-layer chromatography on Silica Gel G (Brinkmann) plates in a solvent system of petroleum ether: ethyl ether: glacial acetic acid $70: 30: 0.8$. Standards and unknowns were made visible by iodine vapor. Fractions of cholesterol ester, free fatty acids, glycerides, and phospholipids were scraped from the plate and either counted directly with scintillant solution, or extracted with chloroform and methanol, dried, and counted with scintillant solution in the liquid scintillation spectrometer.

Identification of the amount of labeled fatty acid present in the 1- and 3-positions in comparison with the 2-position was accomplished by enzymatic hydrolysis of the isolated triglyceride fraction, which was separated from other lipids (12) by silicic acid column chromatography. 


\section{Results}

Study I, B.B., Table $I$. Total recovery of each isotope was $53 \%{ }^{3} \mathrm{H}$ and $57 \%{ }^{14} \mathrm{C}$. Most $(96 \%)$ of the total recovered ${ }^{14} \mathrm{C}$-fatty acid was collected in the $8 \mathrm{hr}$ period after feeding. During this period of absorption, the ratio of lymph isotopes ${ }^{3} \mathrm{H} /{ }^{14} \mathrm{C}$ to meal isotopes ${ }^{3} \mathrm{H} /{ }^{14} \mathrm{C}$ was initially 1.05 , then 0.95 , and then fell to 0.69 (Fig. 1). The fraction of fatty acid label in the 2-position was initially very similar to that of the test meal, but then decreased as absorption continued.

Study II, J. K., Table I. Total recovery of each isotope was $35 \%{ }^{8} \mathrm{H}$ and $49 \%{ }^{14} \mathrm{C}$. The major portion $(96 \%)$ of the total ${ }^{14} \mathrm{C}$-fatty acid recovered was obtained during the first $8 \mathrm{hr}$ after feeding. The isotope ratios in lymph triglycerides were similar to that of the test meal for $4 \mathrm{hr}$ after feeding and then changed to 0.70 (Fig. 1). In this study the distribution of the fatty acids in the triglycerides was determined from the isolated chylomicron fractions, rather than from whole lymph samples. There was very little deviation in the per cent of ${ }^{14} \mathrm{C}$-fatty acid at the 2-position in the lymph compared to the meal.

Study III, W.H., Table I. Total recovery of each isotope was $35 \%{ }^{3} \mathrm{H}$ and $36 \%{ }^{14} \mathrm{C}$. Despite a large volume of lymph $(360 \mathrm{ml})$, the samples for the first $2 \mathrm{hr}$ after feeding had little radioactivity $\left(<0.1 \%{ }^{3} \mathrm{H}\right.$ and $\left.<0.02 \%{ }^{14} \mathrm{C}\right)$. During the subsequent $7 \mathrm{hr}$, there was collected in the lymph lipids $88 \%$ of the total carbon-labeled fatty acid that was recovered; the glycerol-to-fatty acid ratio in

TABLE I

Composition of thoracic duct lymph after gastric or duodenal instillation of doubly labeled glycerides

\begin{tabular}{|c|c|c|c|c|c|}
\hline Time of meal & Lymph volume & Triglyceride & $\frac{\text { Lymph-14 }{ }^{*}}{\text { Total lymph-14 } \mathrm{C} \times 100}$ & $\frac{{ }^{3} \mathrm{H} /{ }^{14} \mathrm{C} \text { sample } \ddagger}{{ }^{3} \mathrm{H} /{ }^{14} \mathrm{C} \text { meal }}$ & $\begin{array}{c}\%{ }^{14} \mathrm{C} \text { in 2-position } \\
\text { of glyceride }\end{array}$ \\
\hline$h r$ & $m l$ & $g$ & & & \\
\hline \multicolumn{6}{|c|}{ Study I (B.B.) 1-:2-monostearin $30: 70$; total recovery ${ }^{3} \mathrm{H} 53 \%{ }^{14} \mathrm{C} 57 \%$} \\
\hline $\begin{array}{c}0-2 \\
2-4 \\
4-6 \\
6-8 \\
8-14 \\
14-20\end{array}$ & $\begin{array}{l}155 \\
170 \\
195 \\
245 \\
520 \\
565\end{array}$ & $\begin{array}{c}0.44 \\
0.90 \\
4.64 \\
5.19 \\
11.8 \\
13.9\end{array}$ & $\begin{array}{r}29 \\
45 \\
16 \\
6 \\
34\end{array}$ & $\begin{array}{l}1.05 \\
0.95 \\
0.81 \\
0.69 \\
0.60 \\
0.58\end{array}$ & $\begin{array}{l}66 \\
42 \\
34 \\
20 \\
20\end{array}$ \\
\hline \multicolumn{6}{|c|}{ Study II (J.K.) 1-:2-monostearin $80: 20$; total recovery ${ }^{3} \mathrm{H} 35 \%{ }^{14} \mathrm{C} 49 \%$} \\
\hline $\begin{array}{c}0-2 \\
2-4 \\
4-8 \\
8-12 \\
12-16\end{array}$ & $\begin{array}{r}85 \\
145 \\
495 \\
420 \\
40\end{array}$ & $\begin{array}{c}0.26 \\
0.73 \\
12.4 \\
0.61 \\
0.09\end{array}$ & \}$^{34} \begin{array}{r}31 \\
31\end{array}$ & $\begin{array}{l}0.98 \\
1.00 \\
0.70 \\
0.42 \\
0.46\end{array}$ & $\begin{array}{l}18 \\
18 \\
13 \\
16\end{array}$ \\
\hline \multicolumn{6}{|c|}{ Study III (W.H.) triolein, labeled fatty acid in 2-position; total recovery ${ }^{3} \mathrm{H} 35 \%{ }^{14} \mathrm{C} 36 \%$} \\
\hline $\begin{array}{c}0-2 \\
2-5 \\
5-9 \\
9-15 \\
15-17 \\
17-21 \\
21-25\end{array}$ & $\begin{array}{l}360 \\
320 \\
540 \\
190 \\
650 \\
630 \\
625\end{array}$ & $\begin{array}{c}1.25 \\
2.69 \\
17.6 \\
5.05 \\
5.49 \\
9.33\end{array}$ & $\begin{array}{l}<1 \\
46 \\
42 \\
12\end{array}$ & $\begin{array}{l}1.12 \\
0.99 \\
0.99 \\
0.88 \\
0.77 \\
0.70 \\
0.77\end{array}$ & $\begin{array}{l}78 \\
55 \\
43 \\
49 \\
40 \\
35\end{array}$ \\
\hline \multicolumn{6}{|c|}{ Study IV (E.G.) triolein, labeled fatty acid in 2-position; total recovery ${ }^{3} \mathrm{H} 24 \%{ }^{14} \mathrm{C} 25 \%$} \\
\hline $\begin{array}{c}1-2 \\
2-3 \\
3-4 \\
4-6 \\
6-8 \\
8-10 \\
10-12 \\
12-14\end{array}$ & $\begin{array}{r}19 \\
60 \\
28 \\
136 \\
93 \\
50 \\
15 \\
87\end{array}$ & $\begin{array}{l}0.70 \\
2.79 \\
1.26 \\
5.06 \\
1.72 \\
1.17 \\
0.02\end{array}$ & $\begin{array}{r}35 \\
40 \\
5 \\
11 \\
\\
8\end{array}$ & $\begin{array}{l}1.01 \\
0.98 \\
0.94 \\
0.86 \\
0.88 \\
0.88 \\
0.84 \\
0.86\end{array}$ & $\begin{array}{r}91 \\
70 \\
74 \\
71 \\
63 \\
65 \\
61 \\
76\end{array}$ \\
\hline
\end{tabular}

* Figures in this column are the percentage of recovered ${ }^{14} \mathrm{C}$-fatty acid collected during each time interval. ‡ Glycerol- ${ }^{3} \mathrm{H}$ label ; ${ }^{14} \mathrm{C}$-fatty acid label. 


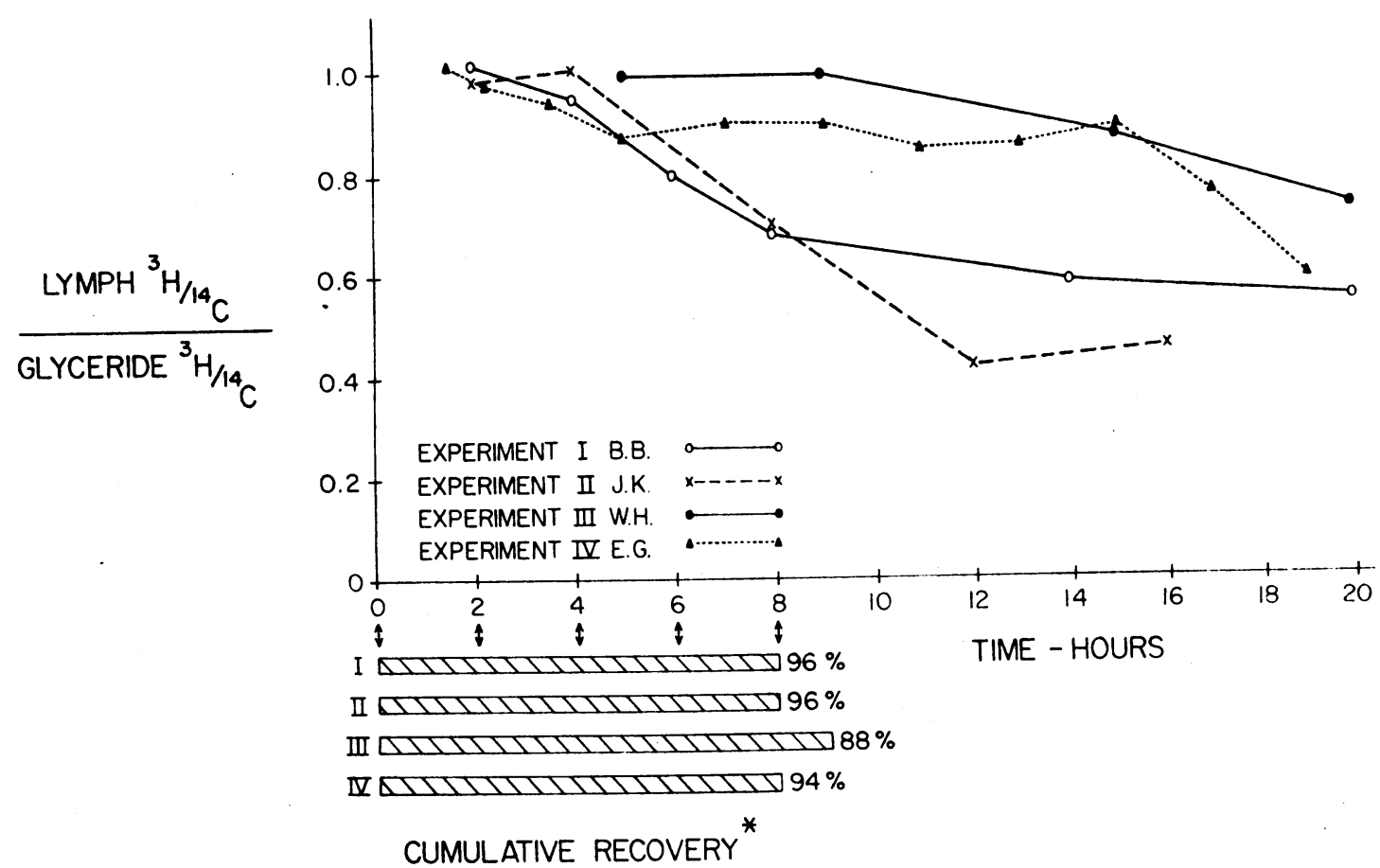

Fig. 1. COMPARISON OF ISOTOPE RATIOS IN HUMAN LYMPH LIPID AND DIETARY TRIGLYCERIDES AFTER GASTRIC OR DUODENAL ADMINISTRATION OF DOUBLY LABELED GLYCERIDES. * Cumulative recovery indicates the period during which the indicated per cent of the total labeled fatty acid that was recovered appeared in lymph lipid.

lymph lipids was the same as the isotope ratio of the meal (Fig. 1). $78 \%$ of the carbon label was in the 2-position for the first $3 \mathrm{hr}$ after feeding and then fell for the subsequent collections.

Study IV, E.G., Table I. The total recovery of each isotope was $24 \%{ }^{3} \mathrm{H}$ and $25 \%{ }^{14} \mathrm{C}$. The per cent of labeled fatty acid in the 2-position of the test triolein was 91 . The $2 \mathrm{nd}$ hr sample, which contained $35 \%$ of the ${ }^{14} \mathrm{C}$ label that was recovered, had $70 \%$ of labeled fatty acid in the 2-position of the lymph triglyceride. This value for distribution of the labeled fatty acid was maintained for $4 \mathrm{hr}$, and then fell during the subsequent $8 \mathrm{hr}$.

Study V, E.G., Table II. The total recovery of the oleic acid- ${ }^{14} \mathrm{C}$ was $48 \%$. A tracer amount of labeled free oleic acid along with $20 \mathrm{ml}$ of unla-

TABLE II

Composition of thoracic duct lymph after oral administration of labeled $\left({ }^{14} \mathrm{C}\right)$ oleic acid and unlabeled triolein

\begin{tabular}{|c|c|c|c|c|}
\hline Time & Lymph volume & $\begin{array}{l}\text { V (E.G.); tota } \\
\text { Triglyceride }\end{array}$ & $\begin{array}{l}\text { ry }{ }^{14} \mathrm{C} 48 \% \\
\frac{\text { Lymph-14 }}{}{ }^{14} \\
\text { Total lymph-14 } \mathrm{C} \times 100\end{array}$ & $\begin{array}{l}\%{ }^{14} \mathrm{C} \text { in } 2 \text {-position } \\
\text { of glyceride }\end{array}$ \\
\hline $\begin{array}{c}h r \\
0-1 \\
1-2 \\
2-2.5 \\
2.5-3 \\
3-4 \\
4-6 \\
6-8 \\
8-10 \\
10-12 \\
12-16 \\
16-20 \\
20-24\end{array}$ & $\begin{array}{r}m l \\
48 \\
52 \\
33 \\
23 \\
60 \\
64 \\
66 \\
72 \\
70 \\
130 \\
110 \\
175\end{array}$ & $\begin{array}{c}g \\
0.25 \\
0.71 \\
1.52 \\
1.23 \\
2.13 \\
1.62\end{array}$ & $\begin{array}{r}<1 \\
6 \\
18 \\
15 \\
27 \\
10 \\
7 \\
4 \\
\\
\end{array}$ & $\begin{array}{l}25 \\
15 \\
12 \\
12 \\
13 \\
18 \\
19 \\
18 \\
\\
22 \\
\\
\\
\end{array}$ \\
\hline
\end{tabular}

* Figures in this column are the percentage of recovered ${ }^{14} \mathrm{C}$. 
TABLE III

Absorption of radioactive glycerol into thoracic duct lymph after duodenal instillation

\begin{tabular}{|c|c|c|}
\hline \multicolumn{3}{|c|}{ Study VI (S.P.) ${ }^{14} \mathrm{C}$-glycerol; total recovery ${ }^{14} \mathrm{C} 4.1 \%$} \\
\hline Time & $\begin{array}{l}\text { Lymph } \\
\text { volume }\end{array}$ & $\frac{\text { Lymph-14 }}{\text { Total lymph-14 }}$ \\
\hline$h r$ & $m l$ & \\
\hline $0-0.5$ & 20 & 0 \\
\hline $0.5-1.0$ & 45 & 3 \\
\hline $1-2$ & 130 & 55 \\
\hline $2-3$ & 80 & 30 \\
\hline $3-5$ & 155 & 9 \\
\hline $5-18$ & 360 & 3 \\
\hline
\end{tabular}
${ }^{14} \mathrm{C}$.

beled triolein was administered to estimate the available hydroxyl sites for esterification on the absorbed monoglycerides within the intestinal cell. In this study, it is assumed that the labeled free oleic acid is almost exclusively utilized for esterification of the hydroxyl groups on the absorbed monoglycerides (from triolein), and not for synthesis via the glycerol phosphate pathway, and in addition, that there is no positional preference for oleic acid at the 1- and 3-positions of the monoglycerides. If the fatty acids were esterified to the absorbed monoglycerides in an entirely random distribution, $33 \%$ of labeled oleic acid should have been found at the 2-position of the lymph triglycerides. The data show that during the bulk of lipid absorption only 12 to $13 \%$ of labeled oleic acid was present at the 2-position, which indicates that considerably more hydrolysis and reesterification were taking place at the 1 - and 3-positions than at the 2-position.

Study VI, S.P., Table III. In contrast to the greater recovery of glycerol when fed as a glyceride, only $4.1 \%$ of the radioactive glycerol was recovered from thoracic duct lymph lipid. Radioactivity appeared one-half hour after the administration of the material, and more than $88 \%$ of the total amount recovered appeared during the first $3 \mathrm{hr}$ of lymph collection after instillation of the radioactive meal into the duodenum. Assay for radioactivity after fractionation by column chromatography and thin-layer chromatography revealed that the radioactivity was almost exclusively in the triglyceride fraction.

\section{Discussion}

The absorption of intact monoglycerides into the intestinal cell wall of rats was demonstrated in
1959 by Skipski, Morehouse, and Deuel (4) who used 1,3 dioleyl-2-deuterostearyl glyceride- ${ }^{14} \mathrm{C}$. Additional observations in the rat by Reiser, Bryson, Carr, and Kuiken (13) with doubly labeled monoglycerides as test meals had previously provided evidence that monoglycerides were absorbed intact into the intestinal cell wall and reesterified in the intestinal cells to triglycerides which then appeared in thoracic duct lymph. These observations were based primarily on analyses of the ratio of the two isotopes, tritum for glycerol and ${ }^{14} \mathrm{C}$ for fatty acids. Mattson and Volpenhein (5) extended these observations by analyzing in the rat the amount of fatty acid label at each position of lymph triglycerides, after feeding monoglycerides, free fatty acids, labeled fatty acids, and triglycerides synthesized with labeled fatty acids at various positions. From these studies they concluded that hydrolysis of the dietary triglycerides in the intestinal lumen yielded 72 parts 2-monoglycerides, 6 parts 1 - and 3-monoglycerides, and 22 parts free glycerol. The 2-monoglycerides, approximately three-fourths of the dietary triglycerides, entered rat intestinal cells intact, and were reesterified to triglycerides without further alteration of the fatty acid at the 2-position.

The particular role that monoglycerides have in furthering human emulsification of dietary lipids has been presented by Hofmann and Borgström (14). Analysis of intestinal lumen contents of man after fat feeding has shown a separation of glycerides into two phases: an oil phase which contains mainly diglycerides and triglycerides and some fatty acid, and a micellar phase which is a combination of bile salts, free fatty acids, and monoglycerides. From the micellar solutions, monoglycerides and free fatty acids are absorbed through the intestinal wall, leaving the bile salts within the lumen to form additional micelles.

The fate of the free fatty acids within the mucosal cell is determined by their chain length and saturation; those of less than 12 carbons are preferentially absorbed by rats directly into the portal blood, whereas longer chain fatty acids are incorporated mainly into triglycerides, and appear in lymph chylomicrons (15). Monoglycerides within epithelial cells may be esterified to di- and triglycerides or cleaved to glycerol and free fatty acids. The 2-monoglycerides are esterified especially rapidly to triglycerides, but esterification 
of 1-monoglycerides lags and these are more likely to undergo hydrolysis particularly if the fatty acids are of short chain length as shown in studies in hamsters (16).

The course of drainage from intestinal lymphatics into the thoracic duct has considerable anatomic variations and is not solely into the left thoracic duct. Although the size of the cannula introduced into the duct makes it unlikely that there is much leakage around the cannula into the venous system, there are other lymphatic-venous channels that are potentially functional and may even actively serve as pathway for intestinal lymph. It has not been possible to estimate the extent of these shunts by sampling plasma and measuring the concentration of radioactivity derived from the feeding, as the turnover time for various lipid classes and the size of the vascular pool make calculations for these channels almost impossible. But blood samples taken during the course of experiments II, III, and IV revealed radioactivity in the triglyceride fraction of plasma. Recoveries of labeled fatty acids in lymph triglycerides in man range from 25 to $60 \%$; these values are less than the 60 to $90 \%$ recoverable in rat studies with labeled fat and cannulation of the main lymph trunk in the abdomen.

The data on the absorption of glycerides obtained from these four patients demonstrate that 2-monoglyceride and its accompanying free fatty acids are the main products of triglyceride digestion and are also the principal forms in which fat is absorbed in man, just as in other animal species. It was formerly held that complete hydrolysis of triglycerides to glycerol and free fatty acids with absorption of these digestion products was a pathway for fat absorption. The results obtained in our studies demonstrate that this pathway can be of only limited importance in man. In Study VI, glycerol- ${ }^{14} \mathrm{C}$ was given into the duodenum in combination with micellar solution of bile salt, monoglyceride, and fatty acid. Such a mixture was shown by Saunders and Dawson in rats (17) to give maximal incorporation of glycerol into lymph triglycerides. It should be noted that only $2.5 \mathrm{~g}$ of lipid was given in the micellar solution along with the radioactive glycerol. This may have reduced the amount of labeled glycerol $(4.1 \%)$ recovered from the thoracic duct lymph since the supply of fatty acids may have been limited at the site of glycerol absorption. The amount recovered here is greater than that reported by Holt, who recovered only 0.7 to $1.2 \%$ of the administered glycerol- ${ }^{14} \mathrm{C}$ in the $24 \mathrm{hr}$ urine collection of a patient with chyluria (18). The labeled glycerol in the thoracic duct lymph was almost exclusively present as triglyceride, as determined by thin-layer chromatography of the extracts of lymph lipids. The remainder of the glycerol was presumably absorbed directly into the portal blood.

Since this study in man shows that little of dietary free glycerol was incorporated into lymph lipids, then free glycerol resulting from the complete hydrolysis of triglycerides in the lumen of the intestine similarly would be incorporated only to a very limited extent into the lymph triglycerides. When labeled glycerol was fed as glycerol-glyceride, however, from 35 to $53 \%$ of the label was recovered in the lymph lipids, and absorption of glycerol therefore must have taken place as a glyceride. This is supported by the ratio of recovered ${ }^{3} \mathrm{H}$ (glycerol) and ${ }^{14} \mathrm{C}$ (fatty acid). In all four studies, during the period when most of the experimental lipid was being recovered, the ratio of the two labeled moieties in the lymph was approximately that in the diet (Fig. 1). Therefore, during the processes of digestion, absorption, and resynthesis, the glycerol and fatty acids remain associated.

The distribution of the labeled fatty acid on the triglycerides of the lymph lipids in Studies I, III, and IV shows that the main bulk of these lipids was absorbed without hydrolysis of the fatty acid located at the 2-position of the dietary glyceride. In these three studies more than half of the labeled fatty acid was still in the 2-position by the time it had reached the lymph. Only in the later time periods, after the main bulk of the dietary lipids had been absorbed, did these values drop.

Study V, in which labeled free oleic acid was given with a large amount of unlabeled triolein, supports the concept that greater hydrolysis and reesterification must take place at the 1 - and 3positions of the dietary fat, since the presence of label that could be introduced into the 2-position was only $12-13 \%$, and not $33 \%$, if random labeling occurred.

In Study II, when a mixture of 1- and 2-monostearin in ratio of $80: 20$ was fed, about $18 \%$ of the labeled fatty acid was in the 2-position of the lymph 
triglyceride, a value similar to that in the dietary fat. In this patient the total recovery of ${ }^{3} \mathrm{H}$ (glycerol) of $35 \%$, although less than that of the ${ }^{14} \mathrm{C}$ (fatty acid) of $49 \%$, indicates that 1-monoglyceride was also absorbed intact. The ratio of the two isotopes in lymph lipids initially was not different from that of the dietary fat. The fate of absorbed 1-monoglycerides in the intestinal wall has been studied in animal experiments; both 1 and 2-monoglycerides are subject to hydrolysis by the intracellular monoglyceride lipase (glycerol monoester hydrolase) (19). However, 2-monoglycerides are more rapidly esterified to triglycerides (16) and incorporated into chylomicrons for delivery into the intestinal lymphatics. Under the conditions of this study, it is likely that 1-monoglycerides were also absorbed intact and esterified.

The observations reported here, together with studies on the hydrolysis of triglyceride in man, and supported by the more extensive absorption studies in animals, suggest that in man after fat ingestion, complete hydrolysis to glycerol and free fatty acid occurs to only a limited extent, especially in the first hours after a meal during which most of fat absorption occurs. The data from these studies indicate that the main route of human fat absorption into the lymph is by the direct esterification of 2-monoglycerides, derived from triglycerides, by the free fatty acids of the intestinal lumen that arise as products of pancreatic lipolysis, or by free fatty acids within the intestinal cell that are derived from monoglyceride hydrolysis and possibly from the circulating free fatty acid pool (11). Glycerol-3-phosphate derived from glucose metabolism or from phosphorylation of free glycerol can be esterified to phosphatidic acid, which then forms diglycerides (20). If large amounts of free fatty acids are present in the diet without glycerides, the glycerol portion of the lymph triglycerides would be formed from glycerol phosphate, with esterification of absorbed free fatty acids via phosphatidic acid to di- and triglycerides (21).

Calculations on the mode of triglyceride absorption in the extensive observations in animals indicate that as much as $72 \%$ of the triglyceride glycerol is absorbed as the 2-monoglyceride and reesterified to triglyceride. Our studies suggest that in man also, on the order of three-fourths of the dietary triglycerides may be absorbed as 2-monoglyceride and incorporated intact into lymph triglycerides. The monoglyceride pathway of fat absorption appears, therefore, to be the predominant route for the normal absorption of dietary triglyceride.

\section{Acknowledgments}

We gratefully acknowledge the technical assistance of Miss Mildred Medick, Mrs. Claire Hakun, and Mr. Robert Volpenhein.

\section{References}

1. Kayden, H. J., J. R. Senior, and F. H. Mattson. 1966. Demonstration that 2-monoglycerides are incorporated intact into human lymph triglycerides. J. Clin. Invest. 45 : 1031. (Abstr.)

2. Hofmann, A. F., and B. Borgström. 1962. Physicochemical state of lipids in intestinal content during their digestion and absorption. Federation Proc. 21 : 43.

3. Reiser, R., and M. C. Williams. 1953. Dihydroxyacetone esters as precursors of triglycerides during intestinal absorption. J. Biol. Chem. 202: 815.

4. Skipski, V. P., M. G. Morehouse, and H. J. Deuel, Jr. 1959. The absorption in the rat of a 1,3-dioleyl-2-deuteriostearyl glyceride- $\mathrm{C}^{14}$ and a 1-monodeuteriostearyl glyceride-C14. Arch. Biochem. Biophys. $81: 93$.

5. Mattson, F. H., and R. A. Volpenhein. 1964. The digestion and absorption of triglycerides. J. Biol. Chem. 239 : 2772.

6. Senior, J. R., and K. J. Isselbacher. 1962. Direct esterification of monoglycerides with palmityl coenzyme $A$ by intestinal epithelial subcellular fractions. J. Biol. Chem. 237: 1454.

7. Mattson, F. H., and R. A. Volpenhein. 1962. Synthesis and properies of glycerides. J. Lipid Res. 3: 281.

8. Folch, J., M. Lees, and G. H. Sloane Stanley. 1957. A simple method for the isolation and purification of total lipids from animal tissues. J. Biol. Chem. 226: 497.

9. Van Handel, E., and D. B. Zilversmit. 1957. Micromethod for the direct determination of serum triglycerides. J. Lab. Clin. Med. 50: 152.

10. Bragdon, J. H. 1951. Colorimetric determination of blood lipids. J. Biol. Chem. 190: 513.

11. Kayden, H. J., A. Karmen, and A. Dumont. 1963. Alterations in the fatty acid composition of human lymph and serum lipoproteins by single feedings. J. Clin. Invest. 42: 1373.

12. Mattson, F. H., and R. A. Volpenhein. 1961. The use of pancreatic lipase for determining the distribution of fatty acids in partial and complete glycerides. J. Lipid Res. 2 : 58.

13. Reiser, R., M. J. Bryson, M. J. Carr, and K. A. Kuiken. 1952. The intestinal absorption of monoglycerides. J. Biol. Chem. 194 : 131. 
14. Hofmann, A. F., and B. Borgström. 1964. The 18. Holt, P. R. 1964. Utilization of glycerol-C ${ }^{14}$ for intraluminal phase of fat digestion in man: the lipid content of the micellar and oil phases of inintestinal glyceride esterification: studies in a patient with chyluria. J. Clin. Invest. 43: 349. testinal content obtained during fat digestion and 19. Senior, J. R., and K. J. Isselbacher. 1963. Demonabsorption. J. Clin. Invest. 43: 247.

15. Bloom, B., I. L. Chaikoff, and W. O. Reinhardt. 1951. Intestinal lymph as pathway for transport of absorbed fatty acids of different chain lengths. $\mathrm{Am}$. J. Physiol. 166 : 451.

16. Brown, J. L., and J. M. Johnston. 1964. The utilization of 1- and 2- monoglycerides for intestinal triglyceride biosynthesis. Biochim. Biophys. Acta. 84: 448. stration of an intestinal monoglyceride lipase: an enzyme with a possible role in the intracellular completion of fat digestion. J. Clin. Invest. 42 : 187.

20. Kern, F., Jr., and B. Borgström. 1965. Quantitative study of the pathway of triglyceride synthesis by hamster intestinal mucosa. Biochim. Biophys. Acta 98: 520.

17. Saunders, D. R., and A. M. Dawson. 1962. Studies 21. Kornberg, A., and W. E. Pricer. 1953. Enzymatic on the metabolism of glycerol by the small intestine in vitro and in vivo. Biochem. J. 82: 477. esterification of $\alpha$-glycerolphosphate by long chain fatty acids. J. Biol. Chem. $204: 345$.

\section{SPECIAL NOTICE TO SUBSCRIBERS}

Post Offices will no longer forward the Journal when you move.

Please notify The Journal of Clinical Investigation, Business Office, 10 Stoughton Street, Boston, Mass. 02118, at once when you have a change of address, and do not omit the Zip Code number. 